\title{
Foraging behavior of selected insectivorous birds in Cauvery Delta region of Nagapattinam District, Tamil Nadu, India
}

\section{S. Asokan ${ }^{1}$ \& A. Mohamed Samsoor Ali ${ }^{2}$}

\author{
Associate Professor, Department of Zoology and Division of Wildlife Biology, A.V.C. College (Autonomous), Mannampandal, \\ Mayiladuthurai, Tamil Nadu 609 305, India. \\ ${ }^{2}$ Senior Research Fellow, Owl Research Project, Department of Zoology, Saraswathi Narayanan College (Autonomous), Perungudi, \\ Madurai, Tamil Nadu 625 022, India. \\ Email: ${ }^{1}$ beeasokan@yahoo.co.in, ${ }^{2}$ amsamsoor@yahoo.co.in (corresponding author)
}

Date of publication (online): 26 February 2010 Date of publication (print): 26 February 2010 ISSN 0974-7907 (online) | 0974-7893 (print)

Editor: C. Srinivasulu

\section{Manuscript details:}

Ms \# 02201

Received 11 May 2009

Final received 06 December 2009

Finally accepted 08 February 2010

Citation: Asokan, S. \& A.M.S. Ali (2010). Foraging behavior of selected insectivorous birds in Cauvery Delta region of Nagapattinam District, Tamil Nadu, India. Journal of Threatened Taxa 2(2): 690-694.

Copyright: $\odot$ S. Asokan \& A. Mohamed Samsoo Ali 2010. Creative Commons Attribution 3.0 Unported License. JoTT allows unrestricted use of this article in any medium for non-profit purposes, reproduction and distribution by providing adequate credit to the authors and the source of publication.

Author Detail: Dr. S. AsokAN is currently teaching students, undertaking and supervising various research activities. He has produced $7 \mathrm{PhD}$ and $40 \mathrm{MPhil}$ students in various fields of Wildlife Biology and Zoology. He has published more than 35 research papers in leading national and international journals.

A. Mohamed SAmsoor Ali obtained his MSc degree in Wildlife Biology from AVC College, Mannampandal in 2003 and he has been working on various fields of ornithology since 2004 .

Author Contribution: The field study was conducted by AMSA under the supervision of SA AMSA analyzed data and wrote the manuscript and SA provided necessary suggestions during manuscript preparation.

Acknowledgements: Financial support for this project was provided by the Ministry of Environment and Forests, Govt. of India, New Delhi. We are grateful to Principal, Staff members of Department of Zoology and Management of A.V.C. College (Autonomous), Mannampandal for having rendered facilities and encouragement. We are thankful to Mr. M. Chakravarthi, Mr. R. Manikannan and Mr. P. Radhakrishnan for their field help.Thanks are also due to the anonymous reviewer for his very constructive comments.

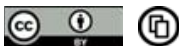

OPEN ACCESS | FREE DOWNLOAD
Abstract: This paper reports the foraging behavior of five insectivorous birds, namely Whitebreasted Kingfisher Halcyon smyrnensis, Small Bee-eater Merops orientalis, Indian Roller Coracias benghalensis, Common Myna Acridotheres tristis and Black Drongo Dicrurus macrocercus in Nagapattinam District of Tamil Nadu, India. The birds used a variety of perch types for hunting insect prey; in general the electric power line was a common perch type used by all species except the Common Myna. The perching and foraging height used by birds were classified into 3 meter categories, up to $12 \mathrm{~m}$. Aerial feeding or hawking in Bee-eaters and ground feeding in Common Mynas were major feeding techniques, recorded $68 \%$ and $86 \%$ of the time respectively. The other three species used gleaning as a feeding technique. The highest niche overlap was recorded between Indian Rollers and Black Drongos and between White-breasted Kingfishers and Indian Rollers.

Keywords: Feeding methods, foraging height, perch types, perching height, substrates.

\section{INTRODUCTION}

Studies on the foraging ecology of birds have been used to explain the community structure, resource use and competition or co-existence in a particular habitat. The foraging guilds in a bird community are described by the way species obtain food, the types of food taken, the foraging substrates exploited, and the heights at which different species forage (MacNally 1994). These data help to compare communities within and between habitats (Recher \& Davis 1998; Gokula \& Vijayan 2000) and also to assess the health of the ecosystem and management needs for the conservation of species and ecosystems (Lawton 1996; Loyn 2002).

High-quality habitats for birds have attributes that influence their hunting success, such as perch height, perch abundance, vegetation density, and prey visibility. It is usually assumed that a perched bird scans a circular area under each perch (Yosef \& Grubb 1992) and that the search area increases with perch height (Sonerud 1992). The significance of perch characteristics (hunting perch) in birds has been highlighted by some authors (Bell 1982; Bell \& Ford 1986; Hutto 1990). The role of foraging substrates in prey selection in insectivorous birds has been noted by Bell \& Ford (1990), Hutto (1990), Asokan (1995) and Gokula \& Vijayan (2000).

The overlap among potential competitors may be used to assess the extent of resource partitioning of the niche dimensions measured (Gokula \& Vijayan 2000). Resource partitioning reduces the effect of competition by decreasing the amount of overlap between the competing species. Some bird species are generalists that will search for food at all heights, on a variety of substrates, and use different methods to obtain food, while other species show varying degrees of specialization (Somasundaram \& Vijayan 2008). Studies of niche segregation have shown a separation in foraging behavior of a few closely related species (Hartley 1953; MacArthur 1958; Sturman 1968; Morse 1970).

Detailed study on the foraging behavior of birds in and around agro-ecosystems of India is limited (Dhindsa \& Saini 1994; Parasharya et al. 1994; Subramaniya 1994). However, some detailed study on foraging behavior has been conducted in the various forest regions of India and other countries (Johnston 1971; Johnsingh et al. 1987; Gokula \& Vijayan 2000, 2007; Amano \& Eguchi 2002; Hino et al. 2002; Murakami 2002; Unno 2002; Jayson \& Mathew 2003; Oppel \& Beaven 2004). Hence, the present investigation was designed to study foraging behavior with special reference to selection of perch types, perching height, foraging height, foraging substrates, foraging methods and niche overlap of the White-breasted Kingfisher Halcyon smyrnensis, Small Beeeater Merops orientalis, Indian Roller Coracias benghalensis, Common Myna Acridotheres tristis, and Black Drongo Dicrurus macrocercus in the Cauvery delta region of Nagapattinam District, Tamil Nadu, India. 


\section{Materials and Methods}

This study was conducted in two different villages, namely Mannampandal and Thiruvalangadu (18 $\left.{ }^{\circ} 18^{\prime} \mathrm{N} \& 7^{\circ} 50^{\prime} \mathrm{E}\right)$, of the Cauvery Delta region in Nagapattinam District of Tamil Nadu, India, from February 2004 to December 2006. Agriculture is the major industry of this area, and contributes a high share of the rice production in the state. Sugarcane, groundnut, green gram, black gram, cotton, etc. are other major crops cultivated in the area. The river Cauvery and its tributaries are major perennial water sources used for irrigation. Woody vegetation is sparse in the form of groves and roadside trees. The predominant tree species found in the study area are Cocos nucifera, Borassus flabellifer, Madhuca indica Mangifera indica, Enterolobium saman, Tamarindus indicus, Ficus benghalensis, Ficus religiosa, Thespesia populnea, Acacia arabica, Odina wodier and Azadirachta indica. Important shrub species are Prosopis juliflora, Jatropha glandulifera and Adhathoda vesica. Plantations of Casuarina equisetifolia, Tectona grandis and Bamboosa arundinacea are also found in the study area. Based on the north-east monsoon the study area is divided into four seasons, namely postmonsoon, summer, pre-monsoon and monsoon. Summer ranges from April to June (with mean maximum temperature of $38^{\circ} \mathrm{C}$ ) and north-east monsoon starts between October and December. The cold season starts in November and may last until January.

The foraging behavior of birds was observed at the study area mostly within the first five hours after sunrise. Individual birds were observed through binoculars and type of perch (electric power lines, trees, shrubs and ground), perching height (height at which the bird was perched while feeding grouped into $0-3 m, 3-6 m, 6-9 m$ and $9-12 m$ ), foraging height (0-3m, 3-6m, 6-9m and 9-12m), foraging substrate (the material from which food is taken by the birds - classified into air, plants and ground) and foraging method (classified into aerial feeding - a bird flew into air to catch flying prey; gleaning - a stationary food item is picked from its substrate by a standing or hopping bird, and ground feeding - the bird picked prey from the ground) being used were noted (Bell \& Ford 1990; Asokan 1995; Gokula 2001). The heights were visually estimated. From the data collected we determined and calculated percent use of different foraging variables used by the insectivorous bird species.

The forage specialization of each foraging variable was analyzed using the Shannon-Weaver index (Shannon \& Weaver 1949). The niche overlap values between the foraging variables of birds were calculated by Pianka's index (Pianka 1973)

$$
\mathrm{O}=\Sigma P_{x a} P_{y a} / \sqrt{\Sigma P_{x a}^{2} \sum P_{y a}^{2}}
$$

Where, $p_{x a}=$ proportion of use of ' $a$ 'th resource by species ' $x$ ' and $p_{y a}=$ proportion of use of 'a'th resource by species ' $y$ '.

\section{Results}

In total, 1194 foraging observations of White-breasted Kingfisher, 1052 of Small Bee-eater, 700 of Indian Roller, 1277 of Common Myna and 1186 of Black Drongo were recorded in the study area. Birds used a variety of perches for hunting the prey. The White-breasted Kingfisher, Small-Bee-eater, Indian Roller and Black Drongo perched predominantly on electric power lines but Common Myna used mostly ground (Table 1). The perching and foraging heights varied from 0 to $12 \mathrm{~m}$. In
Table 1. Percentage of various perch types used by insectivorous birds in the study area

\begin{tabular}{lllll}
\hline Bird species & $\begin{array}{l}\text { Electric } \\
\text { power line }\end{array}$ & Trees & Shrub & Ground \\
\hline White-breasted Kingfisher (1194) & 43 & 48 & 7 & 2 \\
Small Bee-eater (1052) & 43 & 18 & 39 & - \\
Indian Roller (700) & 52 & 43 & 3 & 2 \\
Common Myna (1277) & 5 & 11 & 4 & 79 \\
Black Drongo (1186) & 51 & 36 & 10 & 3 \\
\hline
\end{tabular}

Values in the parenthesis are number of observations

Table 2. Percentage use of various perching and foraging heights by insectivorous birds

\begin{tabular}{llllll}
\hline Bird species & \multicolumn{7}{c}{ Perching height $\mathbf{( m )}$} \\
& $\mathbf{0 - 3}$ & $\mathbf{3 - 6}$ & $\mathbf{6 - 9}$ & $\mathbf{9 - 1 2}$ & H' \\
\hline White-breasted Kingfisher & 12 & 24 & 61 & 3 & 1 \\
Small Bee-eater & 22 & 33 & 44 & 1 & 1.11 \\
Indian Roller & 10 & 15 & 73 & 3 & 0.85 \\
Common Myna & 90 & 5 & 5 & - & 0.39 \\
Black Drongo & 19 & 23 & 56 & 3 & 1.08 \\
& & & Foraging height (m) & \\
White-breasted Kingfisher & 88 & 10 & 2 & - & 0.42 \\
Small Bee-eater & 33 & 37 & 22 & 8 & 1.27 \\
Indian Roller & 80 & 16 & 4 & - & 0.6 \\
Common Myna & 97 & 2 & 1 & - & 0.15 \\
Black Drongo & 69 & 20 & 8 & 3 & 0.89 \\
\hline
\end{tabular}

Table 3. Percentage use of various foraging substrates by insectivorous birds

\begin{tabular}{llll}
\hline Bird species & Air & Plants $^{*}$ & Ground \\
\hline White-breasted Kingfisher & 9 & 64 & 27 \\
Small Bee-eater & 68 & 32 & - \\
Indian Roller & 15 & 66 & 19 \\
Common Myna & 1 & 13 & 86 \\
Black Drongo & 26 & 63 & 11 \\
\hline
\end{tabular}

* considered as herb or shrub or trees

Table 4. Percentage use of various foraging methods by insectivorous birds

\begin{tabular}{llll}
\hline Bird species & $\begin{array}{l}\text { Aerial } \\
\text { feeding }\end{array}$ & Gleaning & $\begin{array}{l}\text { Ground } \\
\text { feeding }\end{array}$ \\
\hline White-breasted Kingfisher & 9 & 64 & 27 \\
Small Bee-eater & 68 & 32 & - \\
Indian Roller & 15 & 66 & 19 \\
Common Myna & 1 & 13 & 86 \\
Black Drongo & 26 & 63 & 11 \\
\hline
\end{tabular}

general, a perching height of $6-9 \mathrm{~m}$ high seemed to have been preferred by all bird species except the Common Myna. The White-breasted Kingfisher, Indian Roller, Common Myna and Black Drongo fed predominantly at $0-3 \mathrm{~m}$. The Bee-eater is shown to forage at heights of $0-3 \mathrm{~m}$ and $3-6 \mathrm{~m}$ at a similar percentage (Table 2). The White-breasted Kingfisher, Indian Roller and Black Drongo used plants (herbs, shrubs and trees) as foraging substrate to find insect prey while Small Bee-eaters used air and Common Mynas used ground as substrates (Table 3). Foraging by gleaning was relatively higher than other methods in White-breasted Kingfisher, Indian Roller and Black 
Table 5. Niche overlaps values among the insectivorous birds in the study area

\begin{tabular}{llllll}
\hline Bird species & $\begin{array}{l}\text { Perch } \\
\text { types }\end{array}$ & $\begin{array}{l}\text { Perching } \\
\text { heights }\end{array}$ & $\begin{array}{l}\text { Foraging } \\
\text { heights }\end{array}$ & $\begin{array}{l}\text { Foraging } \\
\text { substrates }\end{array}$ & $\begin{array}{l}\text { Foraging } \\
\text { Methods }\end{array}$ \\
\hline Kingfisher x Bee-eater & 0.75 & 0.94 & 0.68 & 0.5 & 0.5 \\
Kingfisher x Roller & 0.98 & 0.98 & $\underline{0.99}$ & $\underline{0.98}$ & $\underline{0.98}$ \\
Kingfisher x Myna & 0.17 & 0.25 & $\underline{0.99}$ & 0.51 & 0.51 \\
Kingfisher x Drongo & 0.97 & $\underline{0.99}$ & 0.98 & 0.94 & 0.94 \\
Bee-eater x Roller & 0.76 & 0.88 & 0.74 & 0.59 & 0.59 \\
Bee-eater x Myna & 0.11 & 0.44 & 0.62 & 0.07 & 0.07 \\
Bee-eater x Drongo & 0.84 & 0.96 & 0.81 & 0.72 & 0.72 \\
Roller x Myna & 0.16 & 0.19 & 0.98 & 0.41 & 0.41 \\
Roller x Drongo & $\underline{0.99}$ & 0.96 & $\underline{0.99}$ & $\underline{0.98}$ & $\underline{0.98}$ \\
Myna x Drongo & 0.18 & 0.36 & 0.96 & 0.29 & 0.29 \\
\hline
\end{tabular}

Highest niche overlap values are underlined

Drongo. The Small Bee-eater foraged mainly by aerial feeding and the Common Myna was shown to use ground feeding (Table 4).

Foraging niche overlap: Niche overlap values for variables associated with the insectivory of five bird species are given in table 5.

Perch types: The Indian Roller and Black Drongo had the highest overlap (0.99) while the lowest overlap was between Small Bee-eater and Common Myna (0.11).

Perching height: The niche overlap in perching height was highest between White-breasted Kingfisher and Black Drongo (0.99) while the lowest was between Indian Roller and Common Myna (0.19).

Foraging height:The highest niche overlap in foraging height was between White-breasted Kingfisher and Indian Myna; White-breasted Kingfisher and Common Myna and Indian Roller and Black Drongo (0.99) while the lowest niche overlap (0.62) was found between Small Bee-eater and Common Myna.

Foraging substrates and methods: The highest overlap was found between White-breasted Kingfisher and Indian Roller and Indian Roller and Black Drongo (0.98) while the lowest was found between Small Bee-eater and Common Myna (0.07) (Table 5).

\section{Discussion}

Our results indicate that the five insectivorous bird species used different perch types in the study area. All species, except the Common Myna that preferred to use ground, showed high use of electric power lines. The electric power lines are a common feature in the study area especially around the agricultural habitats. These structures provided suitable perches to birds for detecting prey. The other dominant perch sites used by the birds in our study area were trees and shrubs. With the absence of electric power lines in areas like riverine habitats, birds preferred and readily utilized trees and shrubs as perches. Lammers \& Collopy (2007) stated that avian predators are attracted to over-head utility power lines because they provide perches for various activities, including hunting prey. The White-breasted Kingfisher, Small Bee-eater, Indian Roller and Black Drongo were sit-and-wait predators and they used perches mainly to locate prey and launch their attack. Brookers et al. (1990), Asokan (1995) and Yosef (2004) documented the importance of perches for prey detection / hunting, vigilance, resting as well as other activities of insectivorous birds. However, preference of perch type is dependent on the abundance, availability and type of prey; on the habitat type; and also on the morphological and behavioural characteristics of the bird species themselves.

The White-breasted Kingfisher, Small Bee-eater, Indian Roller and Black Drongo in our study typically perched at the height category of 6-9m to scan an area. The Common Myna perched at a height of $0-3 \mathrm{~m}$ because they are generally ground foragers. Similarly, Sivakumaran \& Thiyagesan (2003) found that Indian Rollers perched at heights of $3-9 \mathrm{~m}$ for locating insect prey. Higher perches may provide a larger field of view and increase chances of detecting prey. However, Shafir \& Roughgarden (1997) and Butler et al. (2005) stated that distance to prey is a key factor influencing the perching height selection in sit-and-wait predators. Bell \& Ford (1986) suggested that the nature and height of perches used by birds is related to the type of prey captured and their seasonal variation. In this study the White-breasted Kingfisher, Indian Roller, Common Myna and Black Drongo foraged mainly at 0$3 \mathrm{~m}$ above the ground, and the Small Bee-eater foraged at wide range of heights $(0-12 \mathrm{~m})$. Brookers et al. (1990) suggested that insectivorous birds in general are height generalists. Vegetation structure, plant species composition, prey abundance and distribution, and interspecific competition significantly affect the foraging height selection of insectivorous birds (Holmes \& Robinson 1981; Robinson \& Holmes 1984).

Three major foraging substrates, namely air, plants and ground, were recognized of which, the White-breasted Kingfisher, Indian Roller and Black Drongo fell under the plantguild because plant offers a greater variety of insect food. The Small Bee-eater used air and Common Myna used ground as major foraging substrates. In the present study, most of the foraging observations were recorded in agricultural and riverine habitats. The birds took insect prey in various foraging substrates viz., paddy/other crops, small stumpy vegetation, and trees, from both habitats. Earlier, some researchers, Holmes \& Recher (1986), Craig (1990), MacNally (1994), Bhatt \& Kumar (2001), Gokula (2001), Murakami (2002), Gokula \& Venkatraman (2003), Gokula \& Vijayan (2007) find out plants as main foraging substrates in forest bird species.

Our results indicate that the White-breasted Kingfisher, Indian Roller and Black Drongo foraged exclusively by gleaning, which suggests that these species adopted a foraging technique suitable to capturing slow moving insect prey on herbs and shrubs. Gleaning is also a common foraging technique reported for many avian species (Recher \& Gebski 1990; Beachly et al. 1995; Amano \& Euguchi 2002; Adamik et al. 2003; Adamik \& Kornan 2004). The Common Myna foraged mainly on the ground surface and the Small Bee-eater used an aerial mode of feeding. The use of foraging technique is 
determined partly by the morphology of birds (Gokula \& Vijayan 2000). Morphological characteristics are closely related to ecological characters in some restricted taxa. Morphological constraints may restrict the range of foraging techniques adopted by any given species. For example, the Small Beeeater having a long bill is suitable for capturing and firmly grasping aerial insects or those of high mobility, the other bird species having short bills are found predominantly to be gleaners. The foraging technique of birds also changed according to habitat type and the abundance of prey items (Poulin et al. 1994; Recher \& Davis 1998; Murakami 2002).

High niche overlap was recorded between Indian Roller and Black Drongo (perch type, foraging height, foraging substrate and foraging method) and White-breasted Kingfisher and Indian Roller (foraging height, foraging substrate and foraging method). Low and high niche overlap values shown by each species can be attributed to the availability of food resources and inter-specific competition in the habitat (Gokula \& Vijayan 2000; Loyn 2002). Hartley (1953), Feinsinger (1976) and Hutto (1981) stated that the distribution, abundance, and quality of food may influence the extent of foraging niche overlap. However, there is no direct information on food resources for this study.

In conclusion, many factors, such as time of day, season, ambient temperature, availability of prey, breeding season, and presence of predators, influence the foraging behavior of birds. Kelly (1998) stated that weather, especially temperature, affects the foraging behavior of insectivorous birds. Several studies have found temperature-related changes in the foraging behavior of birds. Gokula \& Vijayan (2007) stated that food availability, habitat structure, and interspecific competition are also responsible for variation in the foraging behavior of birds.

\section{References}

Adamik, P. \& M. Kornan (2004). Foraging ecology of two bark foraging passerine birds in an old-growth temperate forest. Ornis Fennica 81: 13-22.

Adamik, P., M. Kornan \& J. Vojtek (2003). The effect of habitat structure on guild patterns and the foraging strategies of insectivorous birds in forests. Biologia 58: 275-285.

Amano, H.E. \& K. Eguchi (2002). Foraging niches of introduced Red-billed Leiothrix and native species in Japan. Ornithological Science 1: 123-131.

Asokan, S. (1995). Ecology of the Small Green Bee-eater, Merops orientalis Latham 1801 with special reference to its population, feeding and breeding in Mayiladuthurai, Tamil Nadu, South India. Ph.D. Thesis, Bharathidasan University, Thiruchirappalli.

Beachly, W.M., D.W. Stephens \& K.B. Toyer (1995). On the economics of sit-and-wait foraging: site selection and assessment. Behavioral Ecology 6: 258-268.

Bell, H.L. \& H.A. Ford (1986). A comparison of the social organization of three synoptic species of Australian thronbill (Acanthiza). Behavioural Ecology and Sociobiology 19: 381-392.

Bell, H.L. \& H.A. Ford (1990). The influence of food shortage on inter-specific niche overlap and foraging behaviour of three species of Australian warblers (Aanhizid). Studies on Avian Biology 13: 381-388.

Bell, H.L. (1982). A bird community of low land rain forest in New Guinea. 2. Seasonality. Emu 82: 65-74.

Bhatt, D. \& A. Kumar (2001). Foraging ecology of Red-vented Bulbul Pycnonotus cafer in Haridwar, India. Forktail 17: 109-110.

Brookers, M.G., R.W. Braithwaite \& J.A. Estbergs (1990). Foraging ecology of some insectivorous and nectarivorous species of birds in forests and woodlands of the wet-dry tropics of Australia. Emu 90: 215-230.

Butler, S.J., M.J. Whittingham, J.L. Quinn \& W. Cresswell (2005).
Quantifying the interaction between food density and habitat structure in determining patch selection. Animal Behaviour 69: 337-343.

Craig, R.J. (1990). Foraging behaviour and microhabitat use of two species of white eyes (Zosteropidae) on Saipan, Micronesia. Auk 107: 500-505.

Dhindsa, M.S. \& H.K. Saini (1994). Agricultural ornithology: an Indian perspective. Journal of Bioscience 19: 391-402.

Feinsinger, P. (1976). Organization of a tropical guild of nectarivorous birds. Ecological Monograph 46: 257-291.

Gokula, V. \& L. Vijayan (2000). Foraging pattern of birds during the breeding season in thorn forest of Mudumalai wildlife sanctuary, Tamil Nadu, South India. Tropical Ecology 41: 195-208.

Gokula, V. \& C. Venkatraman (2003). Malabar Parakeet Psittacula columboides in the Siruvani foothills, Tamil Nadu, India. Forktail 19: 138-139.

Gokula, V. \& L. Vijayan (2007). Foraging strategies of birds in partitioning of food resources in dry deciduous forest of Mudumalai Wildlife Sanctuary, Tamil Nadu, India. Journal of Scientific Transaction in Environment and Technovation 1(1): 36-42.

Gokula, V. (2001). Foraging patterns of birds in the thorn of Mudumalai Wildlife Sanctuary, Southern India. Journal of South Asian Natural History 5: 143-153.

Hartley, P.H.T. (1953). An ecological study of the feeding habits of the English titmice. Journal of Animal Ecology 22: 26 I-288.

Hino, T., A. Unno \& S. Nakano (2002). Prey distribution and foraging preference for tits. Ornithological Science 1: 81-87.

Holmes, R.T. \& H.F. Recher (1986). Search tactics of insectivorous birds foraging in an Australian eucalypt forest. Auk 103: 515-530.

Holmes, R.T. \& S.K. Robinson (1981). Tree species preferences of foraging insectivorous birds in a northern hardwoods forest. Oecologia 48: 31-35.

Hutto, R.L. (1981). Seasonal variation in the foraging behavior of some migratory western wood warblers. Auk 98: 765-777.

Hutto, R.L. (1990). Measuring the availability of food resources. Studies on Avian Biology 13: 20-28.

Jayson, E.A. \& D.N. Mathew (2003). Vertical stratification and its relation to foliage in tropical forest birds in Western Ghats (India). Acta Ornithologica 38: 110-116.

Johnsingh, A.J.T., N.H., Martin, J. Balasingh \& V. Chelladurai (1987). Vegetation and avifauna in a thorn scrub habitat in South India. Tropical Ecology 28: 22-34.

Johnston, D.W. (1971). Niche relationships among some deciduous forest flycatchers. Auk 88(4): 796-804.

Kelly, J. (1998). Behaviour and energy budgets of Belted Kingfishers in winter. Journal of Field Ornithology 69: 75-84.

Lammers, W. \& M.W. Collopy (2007). Effectiveness of avian predator perch deterrents on electric transmission Lines. Journal of Wildlife Management 71(8): 2752-2758.

Lawton, J.H. (1996). Population abundances, geographic ranges, and conservation. 1994 Whitherby Lecture. Bird Study 43: 3-19.

Loyn, R.H. (2002). Patterns of ecological segregation among forest and woodland birds in south-eastern Australia. Ornithological Science 1: 7-27.

MacArthur, R.H. (1958). Population ecology of some warblers of northeastern coniferous forests. Ecology 39: 599-619.

MacNally, R. (1994). Habitat specific guild structure of forest birds in southeastern Australia: a regional scale perspective. Journal of Animal Ecology 63: 988-1001.

Morse, D.H. (1970). Ecological aspects of some mixed species foraging flocks of birds. Ecological Monograph 40: 119-168.

Murakami, M. (2002). Foraging mode of four insectivorous bird species under temporally varying resources distribution in a Japanese deciduous forest. Ornithological Science 1: 63-69.

Oppel, S. \& B.M. Beaven (2004). Habitat use and foraging behaviour of Mohua (Mohua ochrocephala) in the podocarp forest of Ulva Island, New Zealsnd. Emu 104: 235-240.

Parasharya, B.M., J.F. Dodia, K.L. Mathew \& D.N. Yadav (1994). Natural regulation of white grub (Holotricha $s p$. Scarabidae) by birds in agro-ecosystem. Journal of Bioscience 19: 381-390.

Pianka, E.R. (1973). The structure of lizard communities. Annual Review of Ecological System 4:53-74. 
Poulin, B., G. Lefebvre \& R. McNeil (1994). Characteristics of feeding guilds and variation in diets of birds species of three adjacent tropical sites. Biotropica. 26: 187-197.

Recher, H.F. \& V. Gebski (1990). Analysis of foraging ecology of eucalypt forest birds: Sequential versus single-point observations. Studies on Avian Biology 13: 174-180.

Recher, H.F. \& W.E. Davis (1998). The foraging profile of a Wandoo woodland avifauna in early spring. Australian Journal of Ecology 23: 514-527.

Robinsons, K. \& R.T. Holmes (1984). Foraging behavior of forest birds: the relationships among search tactics, diet and habitat structure. Ecology 63: 1918-1931.

Shafir, S. \& J. Roughgarden (1997). Testing predictions of foraging theory for a sit-and-wait forager, Anolis gingivinus. Behavioral Ecology 9: 74-84.

Shannon, C.E. \& W. Weaver (1949). The Mathematical theory of Communication. University of Illinois Press, Urbana.

Sivakumaran, N. \& K. Thiyagesan (2003). Population, diurnal activity patterns and feeding ecology of the Indian Roller Coracias benghalensis. Zoos' Print Journal 18(5): 1091-1095.

Somasundaram, S. \& L. Vijayan (2008). Foraging Behaviour and Guild Structure of Birds in the Montane Wet Temperate Forest of the Palni Hills, South India. Podoces 3: 79-91.
Sonerud, G.A. (1992). Search tactics of a pause-travel predator: adaptive adjustments of perching times and move distances by Hawk Owls (Surnia ulula). Behavioural Ecology and Sociobiology 30: 207-217.

Sturman, W.A. (1968). The foraging ecology of Parus atricapillus and $P$. rufescensin the breeding season, with comparisons with other species of Pam. Condor 70: 309-322.

Subramanya, S. (1994). Non-random foraging in certain bird pests of field crops. Journal of Bioscience 19 (4): 369-380.

Unno, A. (2002). Tree species preferences of insectivorous birds in a Japanese deciduous forest: the effect of different foraging techniques and seasonal change of food resources. Ornithological Science 1: 133-142.

Yosef, R. \& T.C. Grubb Jr. (1992). Territory size influences nutritional condition in non-breeding Loggerhead Shrikes (Lanius ludovicianus): a ptilochronology approach. Conservation Biology 6: $447-449$.

Yosef, R. (2004). Perch-site use and inter- and intraspecific aggression of migratory Brown Shrikes (Lanius cristatus) in Southern Taiwan. Biological Letter 4 (2): 113-118. 